\title{
Understanding the Influence of Companion Animal on Child Development: a Literature Review
}

\author{
Risa Juliadilla ${ }^{\natural}{ }^{\bowtie}$, Nia Anggri Noveni ${ }^{2}$ \\ Psikologi, Universitas Gajayana Malang, Indonesia( ${ }^{(1)}$ \\ Psikologi, Universitas Muhammadiyah Purwokerto, Indonesia(2) \\ DOI: $\underline{10.31004 / \text { obsesi.v6i3.1350 }}$
}

\begin{abstract}
Research on human-animal interaction (HAI) is a brand-new thing in Indonesia. However, it is not widely known that human-animal interactions provides positive effect to child development. The study aims to increase literacy regarding human and animal interaction that also looks at the impacts to child development. This study uses an approach of narrative review that examines and analyzes the selected eight papers. This article investigated some of the following aspects of child development in the social-emotional, cognitive and moral development associate with the interaction between children and companion animals. The analysis shows that aspects of social-emotional development assist children, improving their ability to express emotions and conduct emotional regulation. For cognitive development, helps children while interacting with animals and eases children increasing their biological knowledge about animals and children might learn the cognitive empathy related to Theory of Mind. For moral development, it helps children to act pro-social and empathy.
\end{abstract}

Keywords: Children; Companion Animal; Cognitive Development; Socio-emotional Development; Moral Development

\begin{abstract}
Abstrak
Penelitian mengenai Interaksi Manusia dengan Hewan merupakan hal yang baru di Indonesia.Namun belum banyak diketahui bahwa interaksi hewan peliharaan dengan manusia memiliki pengaruh positif khususnya terhadap perkembangan anak. Tujuan penelitian ini adalah menambah literasi mengenai keterikatan manusia dan hewan, serta melihat the influences of animal companions on child development. Penelitian ini menggunakan pendekatan literature narrative review yang menganalisis 8 artikel yang telah peneliti seleksi. Aspek perkembangan anak yang dikaji yaitu aspek perkembangan sosialemosi, kognitif, dan moral terkait dengan interaksi anak dengan hewan peliharaan. Hasil analisis menyebutkan pada aspek perkembangan sosial emosi membantu anak untuk meningkatkan kemampuan mengekspresikan emosi dan melakukan regulasi emosi. Pada aspek kognitif membantu interaksi anak terhadap hewan membantu anak meningkatkan pengetahuan biologis tentang hewan dan anak dapat memahami empati secara kognitif yang terkait dengan Theory of Mind. Pada aspek perkembangan moral membantu anak untuk berperilaku prososial dan berempati.
\end{abstract}

Kata Kunci: anak; hewan peliharaan; perkembangan kognitif; perkembangan sosio-emosional; perkembangan moral

Copyright (c) 2021 Risa Juliadilla, Nia Anggri Noveni

$\square$ Corresponding author:

Email Address : risajuliadilla@unigamalang.ac.id (Malang, Jawa Timur, Indonesia)

Received 4 May 2021, Accepted 22 May 2021, Published 28 September 2021 


\section{INTRODUCTION}

Human-Animal Interaction (HAI) is brand-new for the research trend in Indonesia. Human-Animal interaction practice is undergoing history that utilizes animals for some purposes; for a hunt, search and rescue, livestock, an assistance animal such as a service dog. HAI initiated in 1987 by the National Institute of Health (NIH), held the conference on the benefits of companion animal and its owner. Experts with interdisciplinary were joined and discussed a particular issue on the role of companion animal for child development. The highlighted issue was about how children interact with companion animal and how children's perspective on the companion animal relationship (Esposito, Mccune, Griffin, \& Maholmes, 2011).

Companion animal contributes to child development. Beforehand, it will describe how child develops and what are variable that affects childs development. Development are continuous cycle. This situation is when somebody do the tasks by their ages. Companion animal role is not only things that contribute in children development. Some direct and indirect condition that affect are follows. Child development are the construction of biology, culture and individual (Santrock, 2011). In the figure 1. below is describe Belsky model (parenting model process) with 3 variable that affect child development: child characteristic, parents psychological sources and stress sources with contextual support. These three variable are interconnected and determine child characteristics and development of one to another. As the parents psychological resources covers: personality, jobs, marriage and parenting are consider as a crucial factors. Similar to social links, peers and neighborhoods. The child interaction with animals can bring both positive and negative effect to the childs health and development, depending on the quality of the relationship, attachment and how the child prespective to animals (Mueller, 2021). The relationship among companion animal and children is not monotonous, and can grow collectively with the stages of development. The thing that needs to be concerned is the attachment of companion animal and child interaction, because companion animal ownership is not the only determinant (Wanser, Vitale, Thielke, Brubaker, \& Udell, 2019)

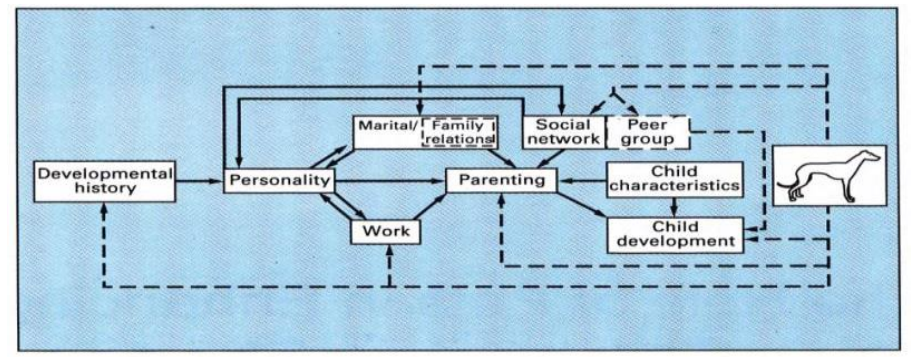

Figure 1. Companion animal Role on Child Development Process ( Endenburg \& Baarda, 1995)

Children and animals are the perfect matches. Child development experts, Gail Melson, discussed how animal leads the child mind through sets of pictures, story, and ideas. In early childhood, children may think anthropocentric, in which they believe that nonhuman beings (animal) have the same character as humans. It is a background behind which children's storybooks with animal characters usually present animal environments with human activities like wearing clothes, having activities, and living in a home. Children are easier to describe traits from an anthropomorphic perspective. It increases children's knowledge about humans and other living creatures about the similarity of animal behavior with humans. The act demonstrates in daily activities, for example, children desire to have a companion animal, animal figures, or wearing peripheral things such as t-shirts, books, classroom things, and many more (Daly \& Suggs, 2010). Companion animal are popular as faithful objects to child emotional expression (Sato, Fujiwara, Kino, Nawa, \& Kawachi, 2019). Companion animal are constantly recognized as family members or friends by children. According to Furman, 
elementary school students consider the companion animal as a lasting relationship, such as "no matter what" and "even if you get mad at each other" (Melson, 2011). Paper presented by Melson \& Schwarz in 1994 proved that nearly half of their sample (a 5-year-old) would share feelings and secrets to their companion animal. Another researcher, Bryan, also revealed that companion animal owners aged 7 to 10 years frequently talk and grumble about emotional experiences with siblings to their companion animal. Their companion animal names are included in the list of 10 most important names in their life, and they consider their companion animal to be more reliable than friends and family (Rothgerber \& Mican, 2014). Dogs and cats are regularly known as companion animals reference or companion animal for children. Dogs, in their presence as companion animal, are prominent because of their devotion. Dogs and other companion animals provide a comfortable, receptive, non-judgmental, and source of unconditional love (Jalongo, 2015). So there is no doubt why dogs perform as a therapy source and become concerned for research for education.

Attachments can explain HAI scientifically. Attachment is a link between animals and humans that is reciprocally useful in health and well-being. The function of attachment is a mechanism of seeking happiness (Wanser et al., 2019). Human attachment to companion animal can be investigated through 3 different theoretical approaches as the foundation of children attachment to companion animal (Jalongo, 2015) such as 1) The Biophilia hypothesis, when the human nature are connect with their environment, to the animal. Humans have a strong bond with animals with the background of the human-animal interaction history (DeLoache, Pickard, \& LoBue, 2011). Children in nature are curious and attractive to animals. Particularly for children, animals provide as object perception that is interesting and emotionally meaningful that can stimulate learning ( $\mathrm{O}^{\prime}$ Haire, McKenzie, McCune, \& Slaughter, 2013); 2) Self Theory, by caring companion animal provide benefits for self-concept, helping to accept weakness and perform respect from others. The bonding with companion animal provides for child participation for balanced, calm, familiar, and proactive relationships; 3) Social Support, the existence of Anthropomorphize in animals can provide social support, helping humans to stay connected. Companion animal bring prosperity to the owner (Juliadilla \& Hastuti, 2018). Children often rely on their companion animal presence for constant companionship when adults or their peers were away.

Realizing the strong bond between humans-animals, this study will promote positive human-animal interaction in various forms, both for companion animal and child development. An attempt to strengthen this theory is by introducing HAI (Human-Animal Interactions) literature on current research trends in Indonesia. Research on how the benefits of companion animals affect a child's development is under the radar and needs more scientific research. The research objective is to enrich the literacy about the influences of companion animals on the development of children.

\section{METHODOLOGY}

This study uses literature review of companion animals related to child development. The analysis in this paper uses the narrative literature review method. The data used are scientific articles that are following the problems that have been studying. The background of the method usage is aim to help and introduce knowledge to readers to understand a particular topic. Since the existing literature about child interaction with a companion animal is out of favor in Indonesia. Human interaction with companion animals is restricted just for the owner and the animal. Even though, lots of positive effects of human-animal interactions. The research objectives are to increase literacy about the benefits of children's interactions with their pets, especially in child development. This study reviewed 8 scientific research articles that examined the existence of animals and human interactions that affect child development.

The study conducted journal screening through PsycINFO, PubMed, Sage, Google Scholar by discovering keywords related to pets, specifically, companion animal, pet, pet ownership, companion animal ownership, and were crossed with the keywords related to 
development such as child development, psychological development, cognitive development, moral, and social-emotional. The inclusion criteria used were the result of journals that investigate the presence, interaction, and pet ownership in the form of cognitive development, moral and socio-emotional in children. The age limitation starts from 1-14 years old, the year the article was searched for the previous decades. The exclusion criteria for research were conceptual research or research that had a meta-analysis methodology and systematic review. After review, the results were analyzed and narrated. The research article quality scoring had done by Critical Appraisal Skills Program Tools (CASP) checklist.

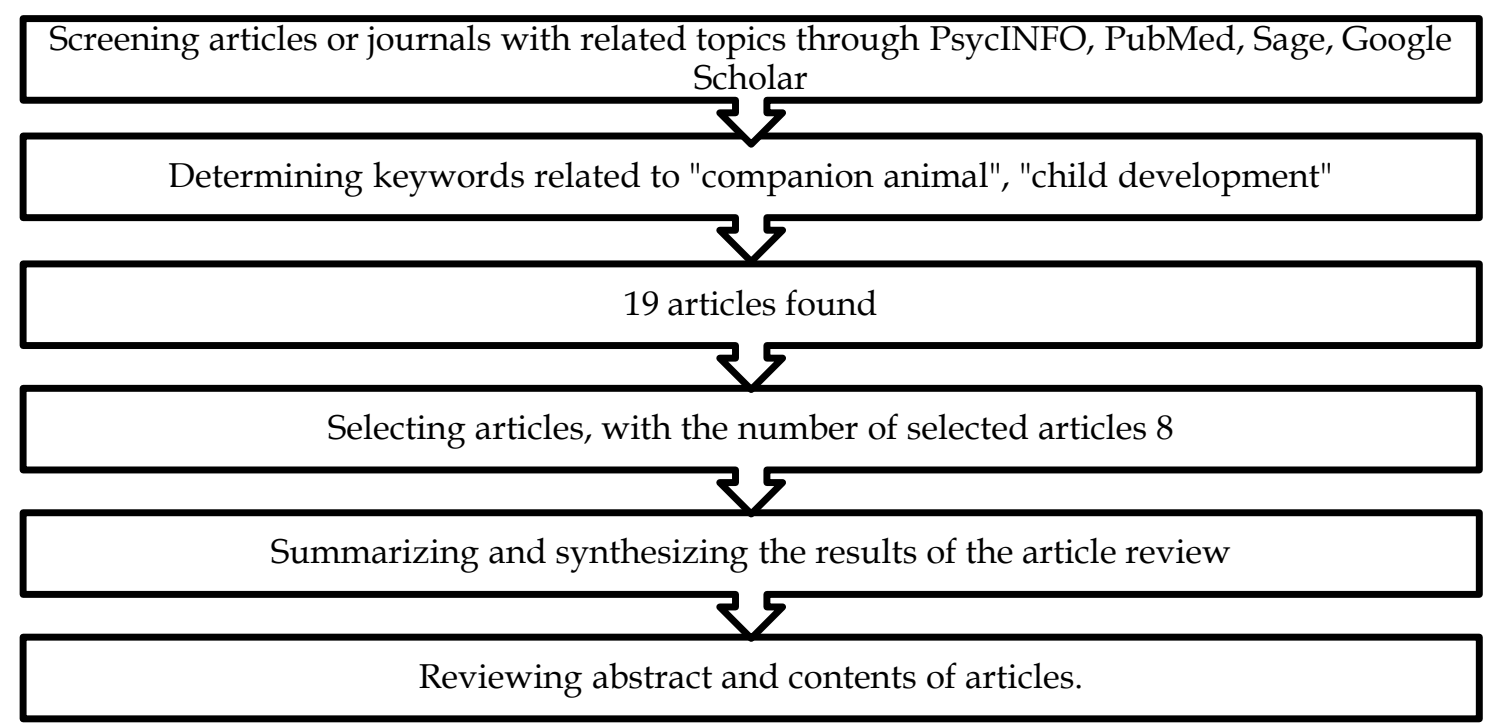

Chart 1. Journal Screening Procedure

\section{RESULTS AND DISCUSSIONS}

Based on the steps that have been followed, 8 articles were reviewed that are described in the table 1.

\section{Socio-emotional Development}

Part of social and emotional development in children is learning how to implement coping strategies. As children get older, they begin to understand stressful situations and learn to cope with them. Social support can serve as a coping strategy for children. The animal can perform as social support does not mean as a myth and can explain scientifically.

Beetz, Julius, Turner, \& Kotrschal, (2012) showed that interacting with dogs shows more significant results than interacting with a person and toy dogs. An experimental study proved when children have a longer time interacting with dogs by stroking, holding, touching dogs before doing TSST-C tasks, where this work stands for pressure and stress. Children's emotional stress decreases when interacting with a companion animal. As a result, children experience a feeling of calm by the release of the hormone oxytocin. Children's experience while interacting with animals can help children learn relaxation and emotional regulation, particularly in stressful situations (Beetz et al., 2012). The dog presence does contribute to reducing stress, but the most important is the physical touch with the dog (by touching and stroking). These also trigger for increasing oxytocin levels.

This research is in line with the research done by Kerns et al., (2018) that examined children 9-11 years old related to dog interactions. This study examines the heart rate response and positive effect on children through the dog presence. The results showed that the positive feedback was higher when the child completed a task together with dogs. As a result, children who had physical contact with dogs had higher positive effects. Children's interaction with a companion animal is associated with significant emotion with positive feedback. When 
children show resilience behavior for coping with stressful situations, the body gets a sympathetic nervous response, while interaction between children and animals occurs: touching or stroking an animal, then the nerve response turns parasympathetic. These show an adaptive response in children when under stressful situations, and the presence of pets helps children coping with stressful situations.

An indicator of socio-emotional development is the increased capacity for expressing negative emotional reactions. Having a pet is an occasion for children to express their emotions without any hesitation. Animals are good listeners who do not make judgments and therefore do not react negatively. Children who have pets have a lower prevalence of bad expression than children who have never possessed a pet. Emotional expression is the key to communication. Children must be able to convey emotional expressions to others. When children express bad emotional expressions, they prone to falter for negative consequences to express their emotions less courageously. Emotion regulation also plays a vital role in proper expression. The existence of pets can reduce emotional barriers and develop children's emotional expressions (Sato et al., 2019)

\section{Cognitive Development}

For a toddler, children have a lack of biological knowledge about humans and others' life. Children's knowledge of animals and biological knowledge develops gradually during early childhood. Every child has a different way of knowing and thinking about animals. This is influenced by demographics. For children that living in an urban area has experience with fictional depictions of animals (for example, pictures; dolls) compared to children who living in rural areas that more familiar with the real animals. Basically, after five years, children start to reason anthropocentric, increasing their knowledge of humans and other lives, thinking about the similarities between human and animal behavior. Children who have pets are capable to relate knowledge about biological things on animal, for example, internal organs, sleeping and time for rest, growth, food, heredity and psychology (interactions and emotions) of animals compared to children who do not have pets. Children who interact with pets are more likely to perceive animals as friends, recognizing that the attributes between animals and humans are similar (Geerdts et al., 2015). Anthropomorphic reasoning on the biology of animals.

The increasing age of the child also affects a companion animal perspective. Children aged 6-10 years prefer animals with a taxonomic similarity with humans. Children also prefer for animal that can interact directly, such as dogs and cats, rather than birds or turtles. Meanwhile, children aged 11-14 years no longer concern with animal taxonomy since they also show an attachment to animals such as rats or iguanas that they treat equally as taking care of dogs and cats. In general, humans tend to love, pay more attention, and build interactions with animals that have phylogenetic similarities that physical, behavioral, and cognitive to humanlike, such as primates and dogs. Age also affects companion animal attachment when someone gets older, less time-spent and interacting with animals because it can occur at work and school activities (Hirschenhauser et al., 2017).

Companion animal interaction with children is also affected by Beliefs about Animal Minds (BAM). BAM is the belief that non-human creatures can think, feel and have the experience emotion. Cognitive and affective empathy presence plays a role in influencing attitudes and well-being in animals (Hawkins \& Williams, 2016). Children who have companion animals have a higher level of BAM. Child BAM is positively associated with attachment to companion animals, humanity attitudes towards animals. Child BAM is closely related to cognitive development with the development of the Theory of Mind and cognitive aspects to understand various animals' emotions. Positive animal interactions are required to boost BAM. Child BAM was associated with caring behavior towards animals and feelings of emotional attachment (Hawkins \& Williams, 2016). 
Table 1. Findings of the companion animal and development children article

\begin{tabular}{|c|c|c|c|c|c|}
\hline Authors & Topics & $\begin{array}{l}\text { Participant } \\
\text { Age }\end{array}$ & $\begin{array}{c}\text { Participant } \\
\text { Gender }\end{array}$ & $\begin{array}{l}\text { Study Type } \\
\text { / Design }\end{array}$ & Outcomes \\
\hline $\begin{array}{lr}\text { Beetz, Julius, } \\
\text { Turner, } \quad \& \\
\text { Kotrschal, (2012) }\end{array}$ & $\begin{array}{l}\text { Socioemotional } \\
\text { Development }\end{array}$ & $\begin{array}{l}7-11 \text { years } \\
\text { old }\end{array}$ & 47 boys & Experiment & $\begin{array}{l}\text { Children's cortisol levels } \\
\text { were lower when supported } \\
\text { by dogs during the tasks } \\
\text { with pressure than humans } \\
\text { assistance and artificial dogs } \\
\text { (toys). }\end{array}$ \\
\hline $\begin{array}{l}\text { Geerdts, Van de } \\
\text { Walle, \& LoBue, } \\
(2015 \mathrm{a})\end{array}$ & $\begin{array}{l}\text { Cognitive } \\
\text { Development }\end{array}$ & $\begin{array}{ll}3-6 & \text { years } \\
\text { old } & \end{array}$ & 24 children & Quantitative & $\begin{array}{l}\text { Children with companion } \\
\text { animal are more associated } \\
\text { with biological traits and } \\
\text { anthropocentric than } \\
\text { children without companion } \\
\text { animal. }\end{array}$ \\
\hline $\begin{array}{l}\text { Hawkins \& } \\
\text { Williams,(2016) }\end{array}$ & $\begin{array}{l}\text { Cognitive and } \\
\text { Moral } \\
\text { Development }\end{array}$ & $\begin{array}{l}\text { 6-13 years } \\
\text { old }\end{array}$ & $\begin{array}{l}1217 \\
\text { children }\end{array}$ & Quantitative & $\begin{array}{l}\text { Children with companion } \\
\text { animal and attachment to } \\
\text { companion animal are more } \\
\text { indicative of Beliefs about } \\
\text { Animal Minds (BAM). }\end{array}$ \\
\hline $\begin{array}{l}\text { Hirschenhauser, } \\
\text { Meichel, } \\
\text { Schmalzer, \& } \\
\text { Beetz, (2017) }\end{array}$ & $\begin{array}{l}\text { Cognitive } \\
\text { Development }\end{array}$ & $\begin{array}{l}\text { 6-14 years } \\
\text { old }\end{array}$ & $\begin{array}{l}84 \text { children } \\
\text { with ages of } \\
6-10 \text { years } \\
\text { old } \\
72 \text { children } \\
\text { with ages of } \\
11-14 \text { years } \\
\text { old }\end{array}$ & Survey & $\begin{array}{l}\text { Age and gender affect the } \\
\text { experience of animals caring. } \\
\text { Children aged 6-10 years old } \\
\text { pay attention to animal } \\
\text { taxonomy such as dogs and } \\
\text { cats, while children ages } 11 \\
\text { years old and over ignore } \\
\text { this point. }\end{array}$ \\
\hline $\begin{array}{l}\text { Kerns, Stuart- } \\
\text { Parrigon, } \\
\text { Coifman, van } \\
\text { Dulmen, \& } \\
\text { Koehn, (2018) }\end{array}$ & $\begin{array}{l}\text { Socioemotional } \\
\text { Development }\end{array}$ & $\begin{array}{l}\text { 9-11 years } \\
\text { old }\end{array}$ & 99 children & Experiment & $\begin{array}{l}\text { Children completing tasks } \\
\text { with companion animal } \\
\text { brings positive effects. } \\
\text { Physical contact with a dog } \\
\text { can give a positive feeling. }\end{array}$ \\
\hline $\begin{array}{l}\text { Bosacki \& } \\
\text { Tardif-Williams, } \\
(2019)\end{array}$ & $\begin{array}{l}\text { Socioemotional } \\
\text { and moral } \\
\text { Development }\end{array}$ & $\begin{array}{l}\text { 6-12 years } \\
\text { old }\end{array}$ & 77 children & $\begin{array}{l}\text { Quantitative } \\
\text { and } \\
\text { Qualitative }\end{array}$ & $\begin{array}{l}\text { Girls are more comfortable in } \\
\text { friendship with companion } \\
\text { animals rather than boys. }\end{array}$ \\
\hline $\begin{array}{l}\text { Sato, Fujiwara, } \\
\text { Kino, Nawa, \& } \\
\text { Kawachi, (2019) }\end{array}$ & $\begin{array}{l}\text { Socioemotional } \\
\text { Development }\end{array}$ & $\begin{array}{l}3.5-5.5 \\
\text { years old }\end{array}$ & $\begin{array}{l}31.453 \\
\text { children }\end{array}$ & Quantitative & $\begin{array}{l}\text { Ownership of animals } \\
\text { contributes a positive effect } \\
\text { on emotional expression. }\end{array}$ \\
\hline Salamah (2020) & $\begin{array}{l}\text { Moral } \\
\text { Development }\end{array}$ & 5 years old & 23 children & Qualitative & $\begin{array}{l}\text { Teaching kindness by loving } \\
\text { animals through the hadiths } \\
\text { of the Holy Quran allows } \\
\text { students to apply } \\
\text { interactions with animals } \\
\text { that trigger moral } \\
\text { enhancement. }\end{array}$ \\
\hline
\end{tabular}

\section{Moral Development}

Moral development includes the thoughts, feelings, and behavior development according to the rules and habits that accomplished when interacting with others (Santrock, 2011). Conscience is an outcome of standard regulation that children have learned on morality, feelings, and behavior. The actual implementation of conscience is when children recognize the concept of right and wrong, demonstrate empathy, sense of guilt, perform discomfort feeling when conducting mistakes or violations. Through companion animal, children get moral learning about issues of justice, kindness, and what is considered morally right about animals and their welfare. Human interaction with animal is relate to beliefs and expression to companion animals, is the basis for the emergence moral emotion that close to moral reasoning. Bosacki \& Tardif-Williams, (2019) explained the interaction of human with companion animal include the process when children feel what animal sense that stimulate 
their empathy and sympathy toward animal. Gender also determines how the child's perception regarding their interaction with the animals. Girls show a close friendships and get more comfortable with companion animals than boys. Gender stereotypes make women grow with sensitivity and have a moral vocabulary. Hawkins \& Williams, (2016) explained that children who interact with animals have the ability about Belief about Mind (BAM) which encourages children to think, feel, and express emotions based on their animal - interaction experiences. Children have an attachment to animals through behavior, so that attitudes towards animals can be the basis for the emergence of pro-social. Pro-social behavior that can foster empathy to prevent acts of violence. When children are able doing perspective taking by distinguishing the other emotional conditions, so it will assist their moral development.

Moral learning can develop through a religious education, as the urgent reason for humans need to love other living things, for example, animals. Salamah, (2020) conducting qualitative research to introduce kindergarten students to animal interactions, including stroking and feeding the animals. The students also taught moral learning through the hadith to treat animals properly. Teaching children to be kind to animals might distort, since children also consume animals, such as chickens and cows. Regarding some dilemma situations, children can learn that consuming animals is not disgraceful, but they emphasize for treating animals properly during their lifetime. Through religious education, children also have the understanding of loving animals in some ways: 1) concern with animal feeding (2) not exploiting animal energy (3) follow the Islam orders to slaughter by sharpening the knives (4) not putting hot iron stamps on animal faces ( 5) do not set animals for practicing arrow (Salamah, 2020). In the development of children's understanding, adult support is needed so that children can properly understand the concept of morality.

Companion animals make a great contribution to moral development. In addition, children need the guidance of the adults around them. Parents are very responsible during the stages of moral development. Moral development is not a gift, but it can be educated and developed by parents.

\section{CONCLUSIONS}

This following literature established the benefits of companion animals with its potential that may explore in terms of child development. Companion animals are not the only factors that contribute to child development, since parents still engage during childrencompanion animal interactions. The way of children treats their pets is affected by the parents' instruction. As an important note the benefits of the child development are not only provide by the companion animal ownership, but also provide by child interaction with the companion animal.

\section{ACKNOWLEDGEMENT}

The authors would like to thank to Psychology Study Program of Universitas Gajayana Malang and Psychology Department of Universitas Muhammadiyah Purwokerto who has provided support for this research.

\section{REFERENCES}

Beetz, A., Julius, H., Turner, D., \& Kotrschal, K. (2012). Effects of social support by a dog on stress modulation in male children with insecure attachment. Frontiers in Psychology, 3(SEP), 19. https:// doi.org/10.3389/fpsyg.2012.00352

Bosacki, S., \& Tardif-Williams, C. (2019). Children's Mental State Talk, Empathy, and Attachments to Companion Animals. Psychology of Language and Communication, 23(1), 284-301. https://doi.org/10.2478/plc-2019-0013

Daly, B., \& Suggs, S. (2010). Teachers' experiences with humane education and animals in the elementary classroom: Implications for empathy development. Journal of Moral Education, 39(1), 101-112. https://doi.org/10.1080/03057240903528733 
DeLoache, J. S., Pickard, M. B., \& LoBue, V. (2011). How Very Young Children Think About Animals. In P. McCardle, S. McCune, J. A. Griffin, \& V. Maholmes (Eds.), How Animals Affect Us Examining the Influence of Human-Animal Interaction on Child Development and Human Health (pp. 85-100). Washington: American Psychological Association. https://doi.org/10.1037/12301-004

Endenburg, N., \& Baarda, B. (1995). The Role of Pets in Enhancing Human Well-being: Effects on Child Development. In R. I (Ed.), The Waltham Book of Human-Animal Interaction: Benefits and Responsibilities of Pet Ownership (1st ed., pp. 7-17). Melton Mowbray: Waltham Centre For Pet Nutrition. https:// doi.org/10.1016/B978-0-08-042284-8.50008-6

Esposito, L., Mccune, S., Griffin, J. A., \& Maholmes, V. (2011). Directions in human-animal interaction research: Child development, health, and therapeutic interventions. Child Development Perspectives, 5(3), 205-211. https://doi.org/10.1111/j.17508606.2011.00175.x

Geerdts, M. S., Van de Walle, G. A., \& LoBue, V. (2015). Daily animal exposure and children's biological concepts. Journal of Experimental Child Psychology, 130, 132-146. https://doi.org/10.1016/j.jecp.2014.10.001

Hawkins, R. D., \& Williams, J. M. (2016). Children's Beliefs about Animal Minds (Child-BAM): Associations with Positive and Negative Child-Animal Interactions. Anthrozoos, 29(3), 503-519. https://doi.org/10.1080/08927936.2016.1189749

Hirschenhauser, K., Meichel, Y., Schmalzer, S., \& Beetz, A. M. (2017). Children Love Their Pets: Do Relationships between Children and Pets Co-vary with Taxonomic Order, Gender, and Age? Anthrozoos, 30(3), 441-456. https:// doi.org/10.1080/08927936.2017.1357882

Jalongo, M. R. (2015). An Attachment Perspective on the Child-Dog Bond: Interdisciplinary and International Research Findings. Early Childhood Education Journal, 43(5), 395-405. https://doi.org/10.1007/s10643-015-0687-4

Juliadilla, R., \& Hastuti H., S. C. (2018). Peran Pet (Hewan Peliharaan) Pada Tingkat Stres Pegawai Purnatugas. Jurnal Psikologi Integratif, 6(2), 153. https://doi.org/10.14421/ipsi.v6i2.1488

Kerns, K. A., Stuart-Parrigon, K. L., Coifman, K. G., van Dulmen, M. H. M., \& Koehn, A. (2018). Pet dogs: Does their presence influence preadolescents' emotional responses to a social stressor? Social Development, 27(1), 34-44. https://doi.org/10.1111/sode.12246

Melson, G. F. (2011). Principles for Human-Animal Interaction Research. In P. McCardle, S. McCune, J. A. Griffin, \& V. Maholmes (Eds.), How Animals Affect Us Examining the Influence of Human-Animal Interaction on Child Development and Human Health (pp. 13-34). Washington: American Psychological Association.

Mueller, M. K. (2021). Human-Animal Interaction and Child Health and Development. 53-67. https://doi.org/10.1007/978-3-030-64085-9_5

O'Haire, M. E., McKenzie, S. J., McCune, S., \& Slaughter, V. (2013). Effects of animal-assisted activities with guinea pigs in the primary school classroom. Anthrozoos, 26(3), 445-458. https://doi.org/10.2752/175303713X13697429463835

Rothgerber, H., \& Mican, F. (2014). Childhood pet ownership, attachment to pets, and subsequent meat avoidance. The mediating role of empathy toward animals. Appetite, 79, 11-17. https://doi.org/10.1016/j.appet.2014.03.032

Salamah, M. (2020). Pemahaman Menyayangi Binatang Bagi Anak Usia Dini Dalam Perspektif Hadits. 8(2), 1-22. https:// doi.org/10.30829/raudhah.v8i2.699

Santrock, J. . (2011). Life-Span Development Perkembangan Masa Hidup (13th ed.; I. Sallama, Novietha, Ed.). Jakarta: Erlangga.

Sato, R., Fujiwara, T., Kino, S., Nawa, N., \& Kawachi, I. (2019). Pet ownership and children's emotional expression: Propensity score-matched analysis of longitudinal data from Japan. International Journal of Environmental Research and Public Health, 16(5). https://doi.org/10.3390/ijerph16050758

Wanser, S. H., Vitale, K. R., Thielke, L. E., Brubaker, L., \& Udell, M. A. R. (2019). Spotlight on the psychological basis of childhood pet attachment and its implications. Psychology Research and Behavior Management, 12, 469-479. https:// doi.org/10.2147/PRBM.S158998 